\title{
Geregtigheid in die struktuur van die Saligsprekings as sleutel tot die eskatologiese verstaan van Jesus as die nuwe Moses in die Bergrede
}

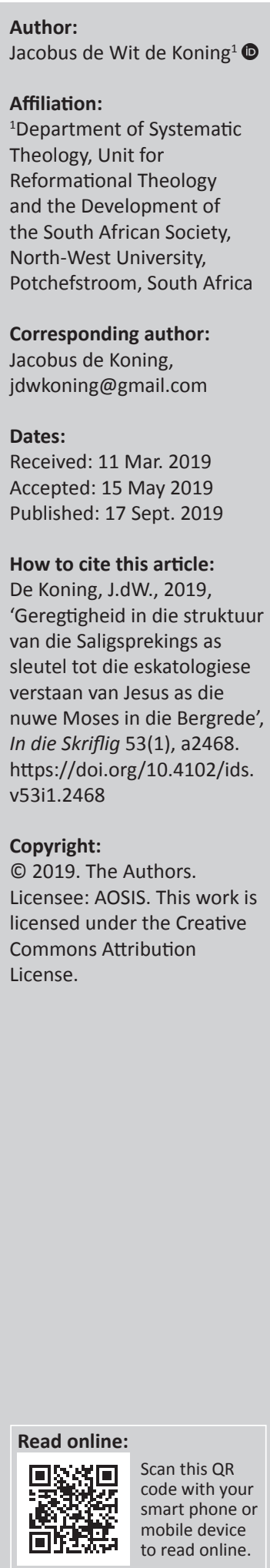

Righteousness in the structure of the Beatitudes as key to the eschatological understanding of Jesus as the new Moses in the Sermon on the Mount. In this article, it is indicated that the

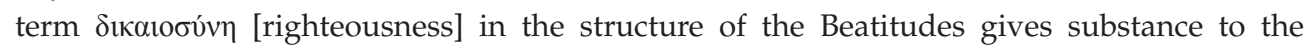
meaning that Matthew wants his readers to see the righteousness which must surpass that of the Scribes and the Pharisees (Mt 5:20). In addition, this righteousness can be regarded as the eschatological commandments of Jesus, the eschatological Moses, which should not be broken. This righteousness is the content of the fulfilled law and prophets, the eschatological will of God for people belonging to his kingdom. The righteousness in the structure of the Beatitudes is therefore the key to the eschatological understanding of Jesus as the new Moses in the Sermon on the Mount.

Keywords: Geregtigheid; Saligsprekings; Bergrede; Eskatologies; Gebooie; Wet; Vervulling.

\section{Inleidend}

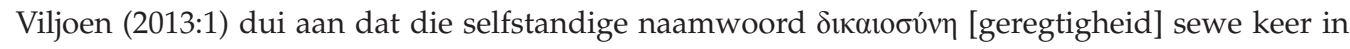
die Matteusevangelie voorkom - meer as in enige geskrif van die Nuwe Testament, behalwe Romeine en 2 Korintiërs. Die term kom net in die uitsprake van Jesus voor. Hierdie uitsprake is óf uniek aan Matteus (Matt 3:15; 5:10, 20; 6:1; 21:32), óf word deur Lukas (Q) gedeel. Die woord

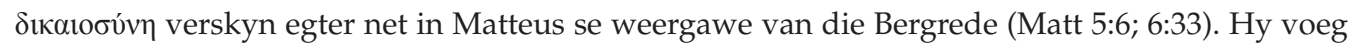
hierdie woord in waar sinoptiese parallelle bestaan en hy gebruik dit herhaaldelik in die Bergrede.

In hierdie artikel gaan daar gepoog word om vas te stel of Matteus se gebruik van die woord

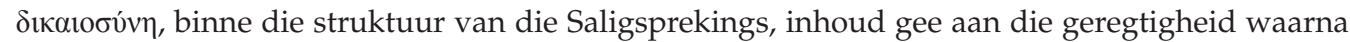
Matteus in hoofstuk 5:20 verwys. Is daar 'n verband tussen hierdie geregtigheid en die 'bepalings' of 'gebooie' wat nie verbreek mag word nie? (Matt 5:19). Meer nog, help 'n verstaan van hierdie geregtigheid in die Saligsprekings om meer sin te maak van die uitsprake in Matteus 5:17-20 aangaande die eskatologiese vervulling of verbreking van die wet en profete deur Jesus?

Die antwoorde op hierdie vrae het ook implikasies vir die verstaan van die wet en die Christelike lewe vir die kerk vandag.

\section{Die Saligsprekings \\ Plasing}

In die eerste hoofstukke van Matteus, voor die Bergrede, val die fokus op die persoon en sending van Jesus Christus. Jesus is die seun van Abraham en Dawid, die Seun van God, en Hy is die een wat die beloftes van die Ou Testament vervul. Jesus is God se gawe van genade, die een deur wie die vernuwing van Israel plaasvind. Christologies beskryf is dit ' $n$ Christologie van vervulling, of 'n Israel - Seun van God Christologie. Matteus sien Jesus dus as die een wat Israel se rol oorneem. Israel word eksplisiet God se seun genoem in Eksodus 4:22 en 32 asook in Jeremia 31:9 en Hosea 11:1. Matteus verwys ook na laasgenoemde vers in Matteus 2:15 en gaan so ver om te sê dat Hosea 11:1 se verwysing na God wat sy seun (Israel) uit Egipte geroep het, in Jesus vervul is. Sy ouers se vlug met Hom na Egipte moes dus volgens Matteus plaasvind sodat Hy uit Egipte kon terugkeer. Israel, as Abraham se nageslag, het weer die rol van Adam oorgeneem (vgl. Wright 1996:23). Die verwysing na vervulling kom nie net in Matteus 2:15 voor nie. Aangesien Matteus by uitstek vir 'n Joodse gehoor skryf, haal hy herhaaldelik uit die Ou Testament aan en maak gebruik van die formule 'sodat die woord vervul sou word wat die Here deur die profeet gespreek het' 
(Matt 1:22; 2:15, 17, 23; 4:14; Holwerda 1995:117). Viljoen (2007) wys op die belangrike rol van vervulling as hy soos volg skryf:

The expression of fulfilment of Scripture had an important function in early Christian circles. The Christian faith had to be legitimatized by reference to the Jewish Scriptures ... when his hermeneutical method is being mirrored against contemporary interpretative methods, it becomes clear that Matthew used the fulfilment motif in a then acceptable way to strategically and persuasively place Jesus' ministry within the unfolding plan of God. (p. 301)

Jesus word daarom in Matteus as die korporatiewe verteenwoordiger van Israel voorgestel in wie en deur wie die beloftes aan Israel vervul word. Poythress (1991:252-255) wys hoe Mattheus 1-4 aandui dat Jesus se lewe analoog is tot die lewe van Moses en die status van Israel as 'n volk. Dit is selfs moontlik om ' $n$ chronologiese parallel te sien tussen die gebeure in Matteus en dié van die volk Israel. Hier kan gedink word aan die volgorde van Rooisee, -woestyn, berg (Sinai) in die geskiedenis van Israel en die volgorde rivier (doop), woestyn (versoeking van Jesus) en berg (Saligsprekings) in Matteus. Binne hierdie vloei van gebeure word die term vervul ook telkens aangetref (vgl. Loader 1997:165). Die frase, die berg opgeklim, word herhaaldelik gebruik om Moses se bestyging van Sinai om die Dekaloog te ontvang, te beskryf (Eks 19:3; 24:12, 13, 28; 34:2, 4; Deut 9:9; 10:1,3). Die feit dat Matteus aandui dat Jesus op die berg klim om te preek, terwyl hy, volgens Lukas, in die laagte preek, is 'n verdere bevestiging van Matteus se doelwit.

Reeds hieruit verwag ons dat dit wat ons in die Saligsprekings kry, iets soos die wet van Moses sal wees, maar tog ook baie anders en meer. Om die vraag te beantwoord, is dit nuttig om weer na die struktuur van die Saligsprekings te kyk.

\section{Struktuur en geregtigheid}

Die Saligsprekings in Matteus 5:3-12 vorm die exordium tot die Bergrede (Viljoen 2013:3). Koch (1974:21-23) het reeds ten gunste van 'n gattungsgeschichtlice verlede agter die Saligsprekings geargumenteer. Hy dui aan dat die genre saligpreking as Griekse literêre formule 'n geskiedenis het. Volgens hom moet hierdie geskiedenis egter nie in die eerste plek in die literatuur van die klassieke Griekse of Hellenistiese wêreld gesoek word nie. Dit moet in die Ou Testament via die Septuagint en in Judaïstiese literatuur gesoek word. Hierdie geskiedenis toon aan dat ' $\mathrm{n}$ deel van Ou Testament, kerugma, in die Nuwe Testament voortgesit word, alhoewel dit met nuwe inhoud gevul word. Van Aarde (1994) dui dan ook hierdie nuwe inhoud aan na 'n deeglike studie van die betekenis van die ( $\mu \alpha \kappa \alpha ́ \rho ı \varsigma, \alpha, o v)$ woordgroep in die Nuwe Testament. Hiervolgens verwys die Saligsprekings na 'n godsdienstige profesie van verlossing wat vreugde en seëning van 'n sekere aard betref wat eskatologiese deelname antisipeer (Van Aarde 1994:163-179). Volgens Viljoen (2013:3) kan die styl van seëning verder op voetspoor van Domeris (1990:68) 'n 'indirekte vermaning' genoem word. God sal hierdie mense vertroos by die finale herstel van alles. Die Saligsprekings het nie net te make met emosies of persoonlike kwaliteite nie, maar met God se gunstige ingesteldheid jeens sekere gedrag en ingesteldhede (Carter 2000:130; Keener 2009:166).

Daar is agt Saligsprekings. Matteus 5:3 en 10 eindig albei met 'aan hulle behoort die koninkryk van die hemele'. Matteus $5: 1-12$ is net ' $n$ uitbreiding op vers 10 . In die middel van hierdie inclusio sien ons nou aan wie behoort hierdie koninkryk; hoe lyk die nuwe volk van God.

Volgens Viljoen (2013:3) is dít wat dus in hierdie agt Saligsprekings gevind word, ten diepste etiese vermanings wat in beloftes en bemoediging van genadige seënings

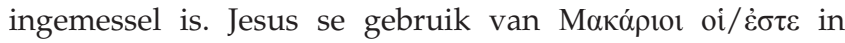
Matteus 5:3 is volgens Keener (2009:165), 'n standaard literêre vorm van die Hebreeuse Bybel soos in Psalm 1:1-2

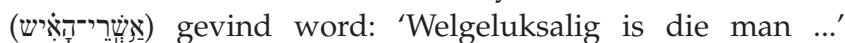
(Ou Afrikaanse Vertaling - OAV).

Só gesien staan die Saligsprekings, volgens Betz (1995:94), in die tradisie van die Joodse wysheidsliteratuur. In die Joodse wysheidsliteratuur is wysheid gegrond op dít van God wat in die Tora openbaar word. Holwerda (1995:117) toon egter aan dat die skaal al meer in die rigting swaai om die saligsprekings deur profeties-apokaliptiese Saligsprekings teenoor wysheids-kultiese Saligsprekings te sien. Dit gaan in eersgenoemde geval nie oor parenetiese vermanings en oproepe tot gehoorsaamheid nie, maar dit is stellings van toekomstige vindikasie, en is juis bedoel om versekering en bemoediging te midde van moeilikheid te gee. Matteus wil doelbewus hê dat sy lesers moet sien dat hierdie Saligsprekings nou die lewe van Jesus se dissipels beskryf asook die parameters vir hulle gedrag binne die lyding wat hulle deurgaan.

Dit is duidelik dat daar twee groepe van vier Saligsprekings elk is.

Die eerste vier Saligsprekings lui:

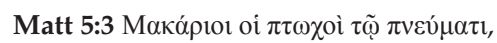

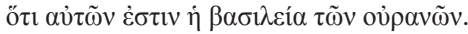

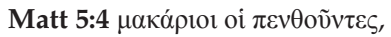

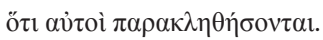

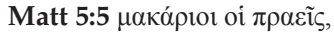

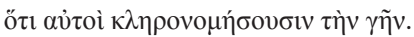

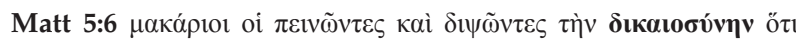

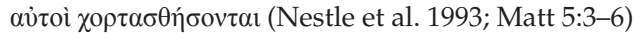

Die eerste groep Saligsprekings eindig dus in Matteus 5:6 met'n verwysing na geregtigheid. Die vier laaste Saligsprekings eindig in Matteus 5:10 weer met 'n verwysing na geregtigheid:

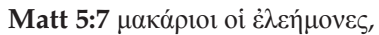

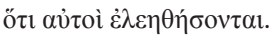

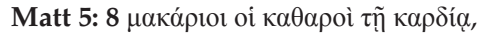

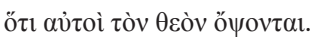

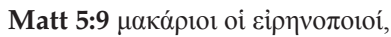

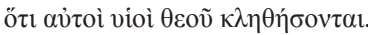

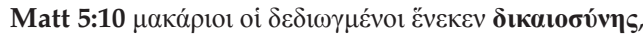

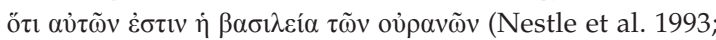
Matt 5:7-10) 
Viljoen (2013:3) toon aan dat hierdie geregtigheid 'n sleuteltema in die Bergrede is. Volgens Viljoen vorm die konsep van geregtigheid in Matteus 5:20 en 6:1 'n inclusio rondom die antitesisse in die halakhah-styl van Matteus 5:21-47. In laasgenoemde verse lig Matteus die nuwe geregtigheid uit wat nou vir die koninkryk vereis word. Allison (1993:147) verkies om nie van 'antitesisse' in Matteus 5:21-48 te praat nie, omdat die Tora nie omvergegooi word nie, maar vervul word. Viljoen (2013:1) meen geregtigheid word gebruik om die regte gedragsnorme van Jesus se volgelinge te onderskei van die buitestanders. Hulle identiteit word hierdeur bepaal.

In hierdie artikel word aangetoon hoe Matteus in die struktuur van die teks van Saligsprekings 'n konkrete aanduiding gee van wat presies die inhoud van hierdie geregtigheid is.

Die eerste groep Saligsprekings soos aangedui, eindig met Matteus 5:6: 'Salig is die wat honger en dors na geregtigheid'; en die tweede groep eindig met vers 10: 'Salig is die wat vervolg word ter wille van geregtigheid.'

Hoe meer daaroor nagedink word, hoe meer betekenisvol word dit. Die drie Saligsprekings wat voor Matteus 5:6 se honger en dors na geregtigheid kom, is almal beskrywings van leegheid of passiwiteit: arm van gees (v. 3), treur oor my toestand en dié van die wêreld (v. 4), en 'n nederige aanvaarding van kritiek sonder om vir myself en my regte te veg, omdat ek gesien het wie ek voor God is (v. 5); (Stott 1985:38-39).

Dit is nie kenmerke van volheid wat oorvloei nie. Dit is wel Saligsprekings en gepas in hulle regte plek, maar dit is nog nie ' $n$ oorvloed van aktiwiteit, goedheid en volheid nie. Die dissipel van Jesus wil meer hê - dít wat Jesus het. Dit maak dus volkome sin dat Jesus na hierdie drie Saligsprekings die volgende sê: 'Salig is die wat honger en dors na geregtigheid' - diegene wat verlang om met geregtigheid gevul te word (Lloyd-Jones 1976:10 e.v.).

In kommentaar oor hierdie vers word daar verskeie voorstelle gemaak oor wat geregtigheid hier sou beteken (vgl. Viljoen 2013:4-5). Die gebruik van die teenwoordige deelwoorde

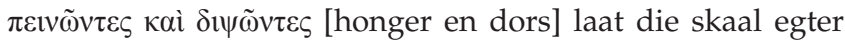
swaai ten gunste van 'n siening, naamlik dat die geregtigheid waarna hier verwys word, met Jesus se dissipels se korrekte lewenstyl, in kontras met dié van die Fariseërs, te make het.

Honger en dors impliseer iets wat gedurig gesoek moet word. Dit is nooit heeltemal binne jou bereik nie. Sulke etiese gedrag dui op die hoogste vorm van dissipelskap. Dit is God se koninkryk en sy geregtigheid wat gesoek moet word. Dit is die strewe na God se wil wat op die aarde moet geskied soos in die hemel (Matt 6:10, 33; Davies \& Allison 2004:453).

Nadat Jesus seën aangekondig het oor diegene wat hulle leegheid besef en daaroor treur, en nie probeer om hulleself te verdedig nie, maak Hy nou 'n verskuiwing vanaf leegheid na volheid deur te sê dat die mense wat honger en dors na geregtigheid, ook geseënd is.

Dit is presies wat ons in die laaste saligspreking vind. Na honger en versadiging in Matteus 6:6, kom 'Salig is die barmhartiges' (v. 7). Die geseëndes is vol en loop oor van barmhartigheid. Hulle is nie net gebroke, hartseer en sagmoedig nie; hulle is nou ook aktief. Hulle is só vol van geregtigheid dat dit, by wyse van spreke, oorloop in dade van barmhartigheid. Matteus 6:8 sê dat hierdie persone rein van hart is en vers 9 sê dat hulle nie net vredevol is nie, maar vredemakers (Stott 1985:39-40).

'n Baie interessante gegewe is dat hierdie tweede groep Saligsprekings met nog 'n verwysing na geregtigheid eindig. Hierdie keer is dit nie ' $n$ honger en dors na geregtigheid wat ons kortkom nie, maar 'n navolging van geregtigheid wat die dissipels se optrede op oorvloedige wyse kenmerk (Carter 2000:136; Davies \& Allison 2004:459).

Die volgende struktuur kan dus onderskei word: Die eerste vier Saligsprekings beskryf die gebroke, stil persoon wat honger en dors na geregtigheid. Die volgende vier Saligsprekings beskryf die barmhartige, rein vredemakers wat vir hulle geregtigheid vervolg word.

Die vraag ontstaan of hierdie struktuur 'n definisie van geregtigheid gee. In Matteus 6:6 word die dissipels beskryf as honger vir geregtigheid, omdat hulle leeg is en dan word hulle vervolg vir geregtigheid omdat hulle gevul is (v. 10). Die logiese afleiding is dat Matteus wil hê dat geregtigheid gedefinieer moet word as dít waarmee die dissipels gevul is en waarvoor hulle vervolg word, naamlik barmhartigheid, reinheid en vredemaking. Is hierdie geregtigheid nie 'n geregtigheid wat méér is as dié van die Fariseërs nie?

\section{Geregtigheid wat méér is as dié van die skrifgeleerdes en Fariseërs}

Jesus sê in Matteus 5:20: 'As julle geregtigheid nie die van die skrifgeleerdes en Fariseërs oortref nie, sal julle nooit die koninkryk van God ingaan nie.' In die res van die hoofstuk wat op hierdie vers volg, is ses illustrasies van hoe Jesus se volgelinge se geregtigheid dié van die wetsonderhouers van daardie tyd moet oortref. Saam met Allison (1993:147) verkies ons om nie te praat van 'antiteses' in Matteus 5:21-48 nie. Volgens Allison is daar, in die lig van Matteus 5:17-20, juis geen antiteses nie, omdat die Tora nie omvergegooi word nie, maar vervul word.

Met watter geregtigheid word die geregtigheid wat meer is gekontrasteer? Met die woordgroep mense van die ou tyd (

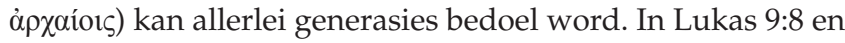
19 word dit gebruik om na die ou profete te verwys. In Matteus 5 kan die woordgroep net so wel die Israeliete aan die voet van Sinai as die generasies uit die tyd van latere wetgeleerdes aandui. Die argument dat die ontvangers van die oorspronklike openbaring altyd met 'die vaders' aangedui 
word, is nie haalbaar nie. Die meer neutrale woorde (mense van die ou tyd) kon gekies word omdat dit oor die vergelyking tussen dít wat vroeër en dít wat nou gesê word gaan en nie soseer oor die verwantskap tussen die vaders en die nageslag nie. Die formule word ook soms verkort na $\dot{\varepsilon} \rho \rho \dot{\varepsilon} \theta \eta$ [daar is gesê] (vgl. byvoorbeeld v. 31; France 1985:119).

Sommige meen dat hier na die tradisie verwys word, aangesien dit mondelings oorgelewer (gesê) is, terwyl die wet op skrif gestel is. Die feit is egter dat die wet deur God gespreek is en as gesproke woord op skrif gestel is. Ook in die Nuwe Testament word daar verwys na die Skrif wat 'gesê het' of die wet wat 'sê' (bv. Rom 9:15, 25; Heb 4:7). In Matteus 2:23 en elders in die boek is daar meermale sprake van 'dit wat gespreek is deur die mond van die profete'. Die uitdrukking Julle het gehoor dat daar gesê is, kan dus net so wel op God se spreke in sy openbaring dui as op die spreke van die vroeëre wetsgeleerdes (Van Bruggen 1999:96).

Die vertaling, deur die mense van die ou tyd, sou die weegskaal ten gunste van die tradisie van die ou wetgeleerdes kon swaai. Die vraag is of so 'n vertaling voorkeur verdien, aangesien daar 'n parallel tussen die sprekendes van ouds en die sprekende Jesus bestaan ('deur die mense van ouds, maar ek sê vir julle'). Daar moet op die feit gewys word dat die parallel eerder getrek is na die publiek wat aangespreek is (daar is gesê aan die mense van die ou tyd, maar ek sê aan julle). In albei gevalle word die datief gebruik, wat op twee maniere geïnterpreteer kan word: as agent of as geaffekteerde. Wanneer daar in die Grieks na diegene verwys word wat die praatwerk gedoen het, word die voorsetsel dia of hupo gebruik (soos in Matt 2:23; 4:14). Daarom moet Van Bruggen (1999:97) se vertaling gekies word, naamlik 'aan die mense van die ou tyd'. Dat daar aan die tradisie gedink word, raak nog onwaarskynliker wanneer in gedagte gehou word dat die uitleg van die wetsgeleerdes ook nog tot die publiek in Jesus se tyd gespreek het.

Verder is dit van deurslaggewende belang dat die verlede tyd, (่̇ $\rho \rho \dot{\varepsilon} \theta \eta)$ 'daar is gesê', hier gebruik word. Jesus vergelyk vroeëre wetgewende spreke tot vroeëre persone dus duidelik met sy eie wetgewende spreke tot daardie generasie.

Dat Jesus sy gebooie vergelyk met die uitsprake van die wet wat Moses aan die mense van die ou tyd gegee het, blyk ook uit die feit dat die voorbeelde op eksplisiete aanhalings uit die tien gebooie betrekking het (Matt 5:21: 'nie doodslaan'; v. 27: 'nie egbreek') of algemene uitsprake uit die wet van Moses (v. 31: die 'skeibrief'; v. 38: 'oog vir 'n oog, tand vir 'n tand'). Soms word daar 'n samevatting van elemente uit die wette gegee (Matt 5:33: 'derde gebod en meineed'; v. 43 'liefde vir die naaste en nie vir die vyand nie') (Allison 1993:148; Van Bruggen 1999:97 e.v.).

Die vergelyking tussen Jesus se gebooie en dié van Moses waarmee die wetsgeleerdes en Fariseërs gemoeid was, toon daarom geen teenstelling nie. Dit gaan om 'n minder-meer verhouding. Dit word veral duidelik uit die feit dat die geregtigheid vir die hemelryk meer is as dié wat die wetgeleerdes van die volk verwag het. Noudat die skare uit Israel met Jesus se koms op die drumpel van die hemelryk gekom het, breek die tyd van volmaaktheid aan (Matt 5:48), omdat mense die gemeenskap met die Vader in die hemel sal geniet (Allison 1993:147).

Struktureel gesien, bestaan Matteus 5:21-48 uit ses paragrawe wat elkeen die waarheid van 5:17-20 illustreer (Allison 1993:147). In hierdie paragrawe kom die geregtigheid van die Saligsprekings, die geregtigheid wat meer is as dié van die Fariseërs, egter ook duidelik na vore:

- Volgens verse 21-26 moet die dissipels nie net nie doodmaak nie; hulle moenie vir hulle broers kwaad bly nie, maar vrede soek (geregtigheid méér as dié van die Fariseërs: vredemakers).

- Volgens verse 27-30 moet die dissipels nie net nie egbreuk pleeg nie; hulle moenie op wellustige wyse na 'n persoon van die teenoorgestelde geslag kyk nie (geregtigheid méér as dié van die Fariseërs: reinheid).

- Volgens verse 31-32 moet die dissipels nie egskeiding goedkeur omdat daar wetlike voorsiening daarvoor gemaak is in die $\mathrm{Ou}$ Testament nie. Hulle moet die geregtigheid oortref wat vrede maak met die hardheid van hart en hulle moet hul verbondbeloftes in die huwelik hou - en nie trou met diegene wat dit nié doen nie (geregtigheid méér as dié van die Fariseërs: reinheid).

- Volgens verse 33-37 moet die dissipels nie net mense wees wat hulle beloftes en eedswerings hou nie, maar hulle moet dié soort mense wees wat nie nodig het om te sweer voordat hulle geglo word nie (geregtigheid méér as dié van die Fariseërs: omdat hulle barmhartig, rein en vredemakers is).

- Volgens verse 38-42 moet die dissipels nie die persoon se oog uitsteek wat hulle oog uitgesteek het nie, maar hulle moet die ander wang draai en kwaad met goed vergeld (geregtigheid méér as dié van die Fariseërs: vredemakers).

- Volgens verse 43-48 moet die dissipels nie net hulle vriende lief hê nie; hulle moet hul vyande liefhê en bid vir diegene wat hulle vervolg (geregtigheid méér as dié van die Fariseërs: barmhartigheid).

Hieruit kan duidelik gesien word wat Jesus bedoel het in Matteus 5:20 toe Hy gesê het dat sy volgelings se geregtigheid dié van die skrifgeleerdes en Fariseërs moet oortref. Dit het alles te doen met die openbaring van barmhartigheid, om radikaal rein van hart te wees en vrede te maak in plaas daarvan om te vergeld.

Dit is insiggewend dat dit ook juis die afwesigheid van hierdie dings is wat Jesus in Matteus 23:13 veroordeel in die Fariseërs wat, volgens Hom, nie die koninkryk sal ingaan nie en ook die deur van die koninkryk vir ander toesluit. Die Fariseërs bind swaar en ondraaglike laste saam en sit dit op die mense se skouers, maar self wil hulle nie 'n vingsr verroer om dit te dra nie (Matt 23:4). Hulle het geen barmhartigheid betoon nie. In Matteus 23:23 word eksplisiet na die feit verwys dat hulle barmhartigheid nalaat. In Matteus 23:25-28 wys Jesus 
dat hulle net rein is van buite, maar nie van binne nie. Hulle het dus geen reinheid van hart nie. Volgens Jesus is hulle nakomelinge van hulle voorvaders; hulle is moordenaars en dus geen vredemakers nie (Matt 23:31).

Die vraag moet nou gevra word of en hoe hierdie geregtigheid verband hou met die bepalings of 'gebooie' waarna Jesus in Matteus 5:17-20 verwys. Voorts moet aangedui word dat die vervulling of verbreking van die wet en die profete in hierdie verse met die geregtigheid in die Saligsprekings verband hou.

\section{Geregtigheid en die 'klein gebooie' op die berg}

Tussen Matteus 5:3-16 aan die een kant, en vers 17 en verder aan die ander kant, is 'n sekere oorgang vanaf 'n positiewe uitvaardiging van gebooie na ' $n$ vergelyking van die gebooie met die geregtigheid van die wetsgeleerdes en Fariseërs te bespeur.

Hierdie verband is van deurslaggewende belang. 'n Noukeurige bestudering van Matteus 5:17-20 toon inderdaad dat Jesus nie hier die bindende geldigheid van die Mosaïese wet leer nie, maar inderwaarheid die bindende geldigheid van die 'nuwe gebooie' wat so pas van die berg afgekondig is. Dit is inderdaad hierdie 'gebooie' wat nie verbreek mag word nie, aangesien dit die inhoud van eskatologiese geregtigheid is. Die aanklag teen die Fariseers maak dan sin: Hulle het juis nie hierdie gebooie gehou nie en hulle geregtigheid is dus nie die geregtigheid wat Jesus van sy volgelinge in die eschaton verwag nie.

Wat in Matteus 5:17-20 eers in die algemeen gestel word (Jesus se gebod eis meer), word vervolgens in verse $21-48$ aan die hand van 'n aantal voorbeelde uitgewerk. Dit beteken nie dat daar geen samehang tussen Matteus 5:33 tot 16 en 17 tot 48 is nie. Dit blyk uit Matteus 5:17 wanneer Jesus sê: 'Moenie dink dat Ek gekom het om die wet of die profete te ontbind nie.'

Die aanleiding tot hierdie opmerking lê nie in die konkrete beskuldiging wat op daardie oomblik teen Hom geuiter is nie. Hierdie opmerking wil eerder die implisiete beskuldiging dat Jesus die wet en profete kom verbreek, voorkom (Van Bruggen 1999:92). In Matteus 5:3 tot 16 spreek Jesus mense salig. Hy bepaal die norme om deel aan die hemelryk te kry. Die volgende vraag ontstaan dan: Beteken dit nou dat Hy afgesien het van die openbaring van God en dat Hy sy eie openbaring in die plek daarvan stel? Geensins; Matteus 5:17 staan die gedagte teen (vgl. 10:34 vir 'n soortgelyke retoriek): 'Moenie dink dat ek gekom het om ...'.

Jesus het gekom; Hy gaan in Israel optree (vgl. Matt 3:11: 'Hy wat ná my kom ...'), maar nie om die wet of profete tot niet te maak nie. ${ }^{1}$

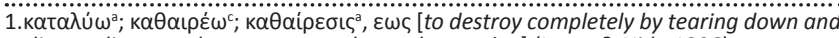
dismantling - to destroy, to tear down, destruction] (Louw \& Nida 1996).
Die heidene wil niks van die wet weet nie. Die Samaritane aanvaar wel die wet, maar nie die profete nie. Matteus wil aandui dat Jesus geen heiden of Samaritaan is nie, maar 'n gelowige Israeliet. Meer nog: Hy kom selfs om te 'vervul'. In hierdie lig moet ' $n$ mens die uitsprake van Matteus 5:3-16 bly sien (Van Bruggen 1999:93).

Die vraag ontstaan wat met 'vervul' ( $\pi \lambda \eta \rho o ́ \omega)$ bedoel word. Du Toit (2018:50) lig, op voetspoor van Trout (2015), vyf hoofbetekenisse van $\pi \lambda \eta \rho$ ó $\omega$ in Matthew 15:17 uit wat van die bevestiging van die wet tot die realisering van wat die wet antisipeer, strek.

Ook Moo (1992:457) teken vyf verskillende interpretasies van hierdie woord aan. ${ }^{2}$ Die eenvoudigste definisie is waarskynlik dié van Louw en Nida (1996) 'to cause something to become full - to fill'.

Poythress (1991:363-377) het 'n uiters belangrike bydrae gelewer deur aan te toon dat $\pi \lambda \eta \rho$ ó $\omega$ nooit die betekenis van 'bevestig' in Grieks kan hê nie: 'it is safe to say that "pleroo" does not have the sense of "confirm" in Greek' (Poythress 1991:377). Hy kom tot hierdie beslissende uitspraak na 'n deeglike analise van alle voorbeelde in die Skrif ${ }^{3}$ wat veral deur Greg Bahnsen gebruik word om aan te toon dat $\pi \lambda \eta \rho$ ó $\omega$ soms die betekenis van 'bevestiging' dra.

Combrink (1991:14) meen dit is opvallend dat die woord wat met $\kappa \alpha \tau \alpha \lambda \dot{\omega}$ gekontrasteer word, nie 'gehoorsaam', 'bevestig' of 'afdwing' is nie, maar $\pi \lambda \eta \rho$ ó $\omega$. Dit is juis hierdie woord wat in die bekende vervullingsitate gebruik word om te beklemtoon dat verskillende aspekte van Jesus se lewe 'n vervulling van die profesieë is. Volgens Combrink aksentueer die omgekeerde volgorde in Matteus 11:13 (profete en wet) die profetiese dimensie van die wet. Dít waarna die Ou Testament vooruit gewys het, breek in Jesus aan, maar tegelyk word dit in Hom getransendeer sonder om dit af te skaf. Die eintlike beliggaming van God se wil is nou in Jesus eerder as in die Ou Testament. Dit gaan vir Matteus om 'n Christologiese verstaan van die wet (Combrink 1991:14).

Van Bruggen (1999:93) se definisie van 'vervul' sluit pragtig aan by die gedagte daarvan as ' $n$ Christologiese verstaan van die wet. Hy meen dat 'vervul' hier dieselfde betekenis het as wat die evangeliste daaraan toeken wanneer daar gepraat word oor die vervulling van die Skrifte. Hy meen dat 'vervul' gesien moet word as dit wat gebeur wanneer die beloftes van die $\mathrm{Ou}$ Testament, wat nog nie gerealiseer het nie, nou in Jesus gerealiseer word.

2.Die vyf beskouinge word deur Moo (1992:457) soos volg geklassifiseer: (1) Jesus vervul die wet deur sy geldigheid te bevestig (die vooronderstelling is dat die Aramese woord qûm agter plereoõ lê); (2) Jesus vervul die wet deur byvoeging: (3) Jesus vervul die wet deur sy volle, oorspronklik bedoelde betekenis uit te lig; (3) Jesus vervul die wet deur sy volle, oorspronklik bedoelde betekenis uit te lig; (4) Jesus vervul die wet deur sy gebooie uit te brei; (5) Jesus vervul die wet deur die
eskatologiese wil van God, wat deur die wet geantisipeer word, te leer.

3.Die gedeeltes wat Poythress ondersoek, sluit die volgende gedeeltes in die Ou

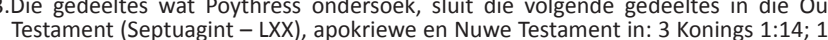
Testament (Septuagint - LXX), apokriewe en Nuwe Testament in: 3 Konings 1:14; 1 ; 2 Korintiërs 10:6; Openbaring 3: 2; Romeine 15:19; Kolossense 1:25. 
France (1985) brei hierop uit as hy die volgende samevatting gee:

So the whole Old Testament, the law as well as the prophets, pointed forward to what Jesus has now brought into being. His ministry brings them to full measure ... by supplying the final revelation of the will of God ... This complex of ideas then lies behind plerosai: Jesus is bringing that to which the Old Testament looked forward; his teaching will transcend the Old Testament revelation, but, far from abolishing it, is itself its intended culmination. (p. 114; France 1989:149)

So gesien, het Jesus nie in Israel opgetree om die openbaring van God geheel (wet) of gedeeltelik (profete) tot niet te maak nie. Hy het juis gekom om te realiseer wat nog ontbreek en oopstaan. Dit wat ontbreek en oopstaan is juis weer die Christologiese verstaan van die wet (vgl. ook Carson 1984:114, 117).

In Matteus 5:18 verleen Jesus onderbou hieraan met 'n gesaghebbende verklaring: $\gamma \grave{\alpha} \rho$. Normaalweg bevestig mense dit wat 'n ander sê met 'amen'. Jesus verleen egter self gesag

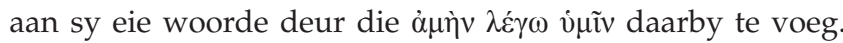
Wie Hom hoor, hoor die Vader. Dit is asof Jesus dikwels 'n onhoorbare uitspraak van 'n onsigbare spreker duidelik hoorbaar met sy amen bevestig. Hierin kom iets te voorskyn van die feit dat Hy dit wat die Vader hom gegee het, bekend maak (Van Bruggen 1999:93).

Dit gee versekering dat nie een jota of tittel van die wet sal verbygaan totdat alles gebeur het nie. ${ }^{4}$ Saam met Carson (1984:145), France (1985:115) en Van Bruggen (1999:93) meen ons dat Matteus 5:18 nie die ewige geldigheid van die wet verkondig nie, maar leer dat geen woordjie in die wet vir niks (of dan verniet) geskryf is nie. Alles het ' $n$ doel; alles wat aangekondig is, sal gebeur. Soos Carson (1984:145-146) dit stel: 'The entire divine purpose prophesied in Scripture must take place; not one jot or tittle wil fail of its fulfillment.' Wanneer die hemel en die aarde verbygaan en die nuwe geskiedenis aanbreek, sal die tyd van die openbaring deur die wet en die profete verby wees. Voor dit sal alles uit die wet en die profete egter ook tot die bedoelde vervulling kom. Die waarde van Matteus 5:18 is dat Jesus vir die vervulling van hierdie belofte 'n waarborg gee. Hy het gekom om te vervul en hy sal sorg dat niks uit die openbaring van God (die wet) onvervuld bly nie.

Na hierdie waarborg in Matteus 5:18, is vers 17 voldoende rugsteuning: Mense moenie dink dat Jesus deur sy onderwys (Matt 5:3 tot 16) die wet en profete misken nie - inteendeel.

In Matteus 5:19 gaan dit oor die houding van die luisteraars: 'Elkeen dus wat een van die minste van hierdie gebooie breek en die mense só leer, sal die minste genoem word in die koninkryk van die hemel.' Daar moet met Van Bruggen (1999:94) saamgestem word dat die vertaling hier misleidend kan wees. Hier staan duidelik: 'een van hierdie klein

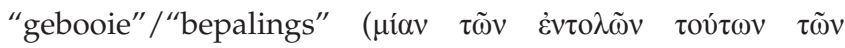
$\dot{\varepsilon} \lambda \alpha \chi i \sigma \tau \omega v)$. Sommige laat hierdie uitdrukking terugslaan op sommige letters - in die Afrikaanse idioom sou ons kon sê: nie een punt op die 'i' sal verlore gaan nie.
Matteus 5:18 ('geen jota of tittel sal verbygaan'). In hierdie vers word dit egter nie 'klein gebooie' genoem nie.

'n Deeglike eksegese van Matteus 5:17 tot 18 lei 'n mens daartoe om vermelding van God se openbaring (wat vervul word) in hierdie verse te vind, maar nie van gebooie (wat gebreek word) nie. In die lig daarvan kan Matteus 5:19 moeilik'n gevolgtrekking wees tot die waarborg wat Jesus in vers 18 gee. Andere laat die uitdrukking 'die minste van hierdie gebooie' vooruit sien op die gebooie wat Jesus in Matteus 5:21 tot 48 gee. Die nadeel van so 'n verbintenis is egter dat Matteus 5:19 dan moeilik is om te begryp in 'n konkluderende sin (oũv [wie dus]). Indirek is hierdie verbintenis egter wel aanwesig in soverre die gebooie in Matteus 5:21-48'n nadere uitwerking van die Saligsprekings in verse 3-16 kan bied (Van Bruggen 1999:94).

Daar word verder, in navolging van Van Bruggen (1999:94), gemeen dat die uitdrukking een van hierdie kleinste gebooie weer terugverwys na die gebooie wat Jesus self in die vorm van Saligsprekings aan die begin van die Bergrede uitvaardig. Hy verorden daar aan wie die hemelryk toekom. In die oë van mense wat vertroud is met die wet en die profete, en die 'groot' nuwe wette wat die hemelryk verwag (Deut 18:15), is dit maar 'klein' gebooie; dinge oor barmhartigheid, reinheid en die stig van vrede - die geregtigheid van die koninkryk.

In die lig van die feit dat Jesus gekom het om God se openbaring (die wet) te vervul, sal 'n mens met hierdie klein gebooie terdeë rekening moet hou. Juis omdat Hy die openbaring en die belofte van God realiseer en die hemelryk bring, sal 'n mens die klein gebooie nie kan verontagsaam nie. Wie dink om in die ryk van die Vader in te gaan met geringskatting van Jesus se gebooie, sal juis in hierdie ryk gering geskat word. Wie egter in die ryk van die Vader wil ingaan met eerbied vir die gebooie van Jesus, sal 'n eervolle onthaal vind en groter opdragte kry (Matt 25:21, 23).

In Matteus 5:20 word bevestig dat die geregtigheid oorvloediger moet wees - méér as dié van die skrifgeleerdes en Fariseërs. Christus handhaaf die geregtigheid wat hulle leer op grond van die wet of profete. Hy wil egter dat Israel, naas die onderwys van die skrifgeleerdes en Fariseërs, ook sy onderwysing ter harte neem en sy woorde sal hoor en doen (vgl. Matt 7:24, 26). Naas die onderwys van die wetgeleerdes kom die 'Ek sê vir julle' van Jesus wat gekom het om God se openbaring te vervul. Wanneer die gedagte van 'n komplimenterende openbaring in Matteus 5:17 verwerp word, word gemeen dat dit wel in verse 19-48 te sien is.

Die logiese gedagtegang van Matteus 5:17-20 kan dus so saamgevat word: Aangesien Jesus God se wet juis kom vervul (v. 17 gerugsteun deur v. 18), sal elkeen wat God liefhet ook vir sy gebooie oor die ingaan in die koninkryk respek hê (v. 19 gerugsteun deur v. 20). Israel leef onder die seën van die wet en die profete, en word geroep om Jesus se gebooie aan te neem, aangesien Hy die wet en die profete vervul en God se beloofde koninkryk sal laat realiseer.

Hulle word geroep tot die eskatologiese geregtigheid van die Saligsprekings - die geregtigheid wat barmhartigheid, 
reinheid van hart en vredemaking as inhoud het. Wat presies met eskatologiese geregtigheid bedoel word, word in die volgende afdeling verder beredeneer.

\section{Die eskatologiese konteks van die Bergrede}

Daar is reeds na die feit verwys dat ons waarskynlik in die Saligsprekings met profeties-apokaliptiese Saligsprekings te doen het. Dit is van uiterste belang om hierdie eskatologiese perspektief, wat seëning en gawe reflekteer, in gedagte te hou. Dat die beloftes van Jesaja 60-61 die Bergrede en spesifiek die eerste vier Saligsprekings ten grondslag lê, word al meer algemeen aanvaar. In Jesaja 56-66 is die volk terug in Jerusalem na die ballingskap en die tempel is herbou Dit gaan egter nie goed met die volk nie. Hulle kry swaar en is moedeloos. Jesaja verkondig dan dat God met sy volk op pad is na 'n nuwe bestemming, 'n nuwe Jerusalem, 'n nuwe hemel en aarde (Prinsloo 1999:773). In Matteus se geslagregister kry ons in 5:17 die volgende uitspraak: 'Al die geslagte dan van Abraham tot Dawid is veertien geslagte, en van Dawid tot die Babiloniese ballingskap veertien geslagte, en van die Babiloniese ballingskap tot Christus veertien geslagte.'

Matteus wil oënskynlik hierdeur aantoon dat die balllingskap die einde van die Dawidiese opvolging beteken het en 'n groter koning dus verwag kan word (Nixon 1982:818). Daar is waarskynlik meer agter hierdie verwysing na die ballingskap. Deur nie na die terugkeer uit die ballingskap te verwys nie, maar direk op Jesus se koms, toon Matteus aan dat Jesus die einde van die ballingskap is en daarmee saam, per implikasie, die vervuller van die beloftes rondom die terugkeer uit ballingskap. Jesaja 60 se verwysing na die lig van God se teenwoordigheid in Jerusalem en die verantwoordelikheid van die inwoners van Jerusalem, is betekenisvol. Dit is duidelik nie reeds ' $n$ werklikheid na die ballingskap nie, maar word in profetiese hoop uitgespreek. Die inwoners sal almal regverdiges wees (Jes 60:21) - mense wat dus geregtigheid doen. Dit is hulle wat die aarde vir ewig sal besit (Jes 60:21). Van hierdie inwoners van Jerusalem word gesê dat die nasies sal kom na die lig wat uit Jerusalem sal skyn (Jes 60:3). Dit is moeilik om te ontken dat hierdie gedeeltes 'n belangrike rol in Matteus se weergawe van die Saligsprekings en Bergrede speel. Die dissipels, wat nou die geregtigheid van die Saligsprekings doen, is die stad op 'n berg wat lig gee (Matt 5:13). Daar is nou hoofsaaklik na Jesaja 60 verwys. Jesaja 61 se eerste vier verse vorm sonder twyfel

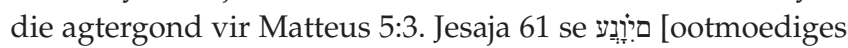
(OAV) of mense in nood (NAV)] word in die LXX met 'armes' vertaal. Dumbrell (1981:1-21) het baanbrekerswerk in hierdie verband gedoen. Nadat hy oortuigend aangedui het dat die verband tussen $\pi \tau \omega \chi$ oì (Matt 5:3) en die begin van God se heerskappy duidelik in Jesaja 61 tot 62 na vore kom, dui hy (Dumbrell 1981) die algemene verband met Matteus 5:3 van hierdie materiaal soos volg aan:

To the existent community of God's people, the consolation of Israel has now come. The disciples who in Galilee had been drawn to the messianic light have now become, and are designated in Matthew 5 verse 3 as such, the nucleus of the kingdom. (p. 9)

Anders gestel: die dissipels is nou die 'profete' van die nuwe verbond of koninkryk - soos Dumbrell (1981:10) dit stel: 'prophetic sufferings indicate a prophetic - type ministry, and prophetic - type ministry understood in Old Testament terms is a ministry which operates within the framework of covenant'.

Selfs in die Saligsprekings word die Christologie van vervulling dus voortgesit. In die Saligsprekings bied Jesus Homself aan as God se gesalfde dienskneg wat die beloofde seënings uitgiet. Soos met 'n seëning, spreek die Saligsprekings in werklikheid seënings uit oor die armes en verdruktes. Indien dit wel so is dat Jesaja 61 die belofte is wat vervul word in die eerste Saligspreking, dan moet dit ook wees dat die 'armes in gees' nie net na geestelike armoede en berou oor sonde verwys nie, maar ook na sosiale, ekonomiese en politieke verdrukking. Aan sulke verdruktes en armes, verkondig Jesus dat die seënings van die koninkryk alreeds op hande is; seënings van vergifnis van sonde, maar ook seënings van geregtigheid en reg, alhoewel die volheid daarvan op toekomstige vervulling wag.

Jesaja beskryf die herstelde Israel ook as 'terebinte van geregtigheid; 'n planting van die HERE, tot sy verheerliking' (61:3) en hy beloof dat 'die Here HERE geregtigheid en lof laat uitspruit voor die oog van al die nasies'.

Jesus se seënings in die Saligsprekings is direk verbind aan die koninkryk van God en sy geregtigheid, wat alreeds gekom het maar finale vervulling afwag. Die Saligsprekings spreek 'n huidige en toekomstige seëning uit. Aangesien Jesus se seënings in hulleself 'n eskatologiese vervulling van die Ou-Testamentiese beloftes is, is die etiese gedrag wat in die Saligsprekings beskryf word alreeds 'n reaksie op die manifestasie van God se koninkryk en daardie gedrag word weer 'n manifestasie van die geregtigheid wat verwag word vir die ingaan in die koninkryk van God. Met geregtigheid sowel as die koninkryk van God, is die beweging van genade vanaf Goddelike optrede na menslike reaksie deur die persoon en werk van Jesus. Gehoorsaamheid is op sigself eskatologies. Met ander woorde, dit word gemotiveer, in staat gestel en gevorm deur die hoopvolle deelname in die nuwe realiteit van die koninkryk wat in die geskiedenis deur die geregtigheid van Jesus inbreek (Holwerda 1995:119).

Dit is slegs wanneer Matteus se eskatologiese Christologie verstaan word dat daar op verantwoordelike wyse met Matteus se siening van die wet omgegaan kan word. Hierdie eskatologiese konteks word ook in Matteus 5:13-16, net voor verse 17-21, gevind in Jesus se 'sout en lig'-uitsprake wat as 't ware'n opsomming van die Bergrede tot op daardie punt vorm. Dumbrell (1981) dui aan dat daar met die beeld van sout steeds binne die raamwerk van 'profetiese lyding' beweeg word:

Like the Servant community before them, the fulfillment of their mission to the world will involve suffering; yet the very fact of suffering will confirm their covenantal role as the salt of the land. (p. 13) 
As sout verseker hulle dus die voortsetting van Israel se roeping. Wat lig betref, wys Jesus sy dissipels aan om 'n 'stad op 'n berg te wees' wat die nasies verlig. Hierdie lig neem die vorm aan van goeie dade wat die geregtigheid van God se lig reflekteer. Dit is duidelik dat die dissipels veronderstel is om die eskatologiese stad te wees waarvan die lig die teenwoordigheid van die Here reflekteer (Jes 60:1) en wat God se weë aan die nasies leer sodat hulle daarin kan leef. Die weë van God is egter niks anders nie as die 'nuwe gebooie' op die berg, die geregtigheid van die Salisprekings en die Bergrede wat nou die dissipels sal kenmerk. Oor hierdie eskatologiese wet word reeds in Jesaja 2 geprofeteer wanneer daar vorentoe gekyk word na wat sal gebeur indien die volk weer na Jerusalem terugkeer. Ons het nou reeds gesien dat dit in Jesaja 60-61 bewaarheid word, maar dat dit steeds op verdere eskatologiese vervulling gewag het: 'Want uit Sion sal die wet uitgaan en die woord van die HERE uit Jerusalem' (Jes 2:3).

Indien die eskatologiese interpretasie van Matteus 5:15 korrek is, word dit duidelik waarom Matteus op hierdie punt die wet in Matteus 5:17-48 bespreek. Ons sou dus voorlopig wou sê dat die wet waarna Jesus in die Bergrede verwys as die 'vervulde' wet, niks anders is nie as die wet vanuit Sion wat vir die nasies bedoel is. Dit is die uitleef van hierdie wet wat van die dissipels 'n lig vir die nasies sal maak.

Die hele konteks tot en met Matteus 5:17-20, skep dus die verwagting dat ook dit wat hír gevind word te make het met 'n groter, eskatologiese geregtigheid en standaard as wat die geval was in Israel. Hier het ons te make met die Een wat groter is as Moses (Israel) en wat laasgenoemde se rol oorneem en dit tot 'n heerliker, groter eskatologiese hoogtepunt bring. Met ander woorde, Hy is die vervulling van eskatologiese verwagting; die kulminasie van Israel se geskiedenis.

Die vraag is nou of ons moet praat van ' $\mathrm{n}$ 'Messiaanse Tora'. Saam met Allison (1993:185) wil ons positief antwoord: 'Jesus is die Moses-agtige Messias wat die eskatologiese wil van God van 'n berg af afkondig, tipologies gelykstaande aan Sinai.'

Daar moet toegegee word dat met die benaming Messiaanse Tora nie aangeneem kan word dat dit 'n goed-gedefinieerde konsep in Matteus se wêreld is nie; ook nie dat ons gebruik daarvan vry van twyfelagtigheid is nie. Terselfdertyd is dit wel so dat 'n ondersoek van sekere tekste die feit van ' $n$ Messiaanse Tora in Matteus ondersteun.

5.Allison (1993:186) gee dievolgende voorbeelde: Jesaja 42:1-4: die dienskneg ( = Jesus die Messias vir Matteus; vgl Matt 12:18-21) sal mispat en tora bring. Die Messiaanse orakel Messias vir Matteus; vgl Matt 12:18-21) sal mispat en tora bring. Die Messiaanse orake in Numeri 24:17 verwys, volgens CD 7:18, na 'the Interpreter of the law'. 4 Q175 haa Deuteronomium 18:18-19 aan in 'n bundel van Messiaanse tekste, en implisee daarmee dat die Qumran gemeenskap 'n eskatologiese profeet soos Moses verwag van wie God gesê het: 'Ek sal my woorde in sy mond lê en hy sal hulle leer alles wat ek hom beveel' [outeur se vertaling in Afrikaans]. II qMelch. 2:15-21 wys daarop dat " $n$ gesalfde een, 'n prins' (vgl. Dan 9:25) vrede en verlossing sal verkondig (vgl. Jes 52:7) en Hy sal aan diegene wat in Sion treur, instruksie gee (vgl. Jes 61:2-3) 'in al die eeue van die wêreld'. En. 51:3: die uitverkore Een, die Seun van die mens, sal op God se troon sit en 'uit sy mond sal al die geheime van wysheid kom' (vgl. Jes 46:3; 49:3-4). Ps. Sol.17:43: die Messias se 'woorde sal suiwerder as die suiwerste goud wees; die beste. Hy sal die volke in die vergaderinge oordeel; die stamme van die geheiligdes. Sy woorde sal wees soos die woorde van die heiliges, onder die woorde van die heiliges, onder geheiligde volke.' Tg Onq: 'die Messias en dié saam met hom sal die Tora bestudeer'. Targ Jes.?: 'vrede sal kom deur die Messias se lering en die wat "om sy woorde vergader" sal vergewe word.' Gen. Rab.98:9: Hier word verwys na die feit dat die Messias die woorde van die Tora sal verhelder en vir die ballinge van Israel 30 gebooie sal gee. By bogenoemde kan ook Johannes 4:25 gevoeg word waar die Samaritaanse vrou die hoop uitspreek dat wanneer die Christus kom, Hy 'ons alle dinge sal verkondig' (vgl. Memar Marqah 4:12)
Matteus assosieer waarskynlik Jesus se amp as leraar met sy status as Messias. Dit volg uit die verwagting waarvan daar in baie tekste uit verskillende tye en plekke sprake is. Volgens hierdie tekste sal die Messias of een of ander eskatologiese figuur eskatologiese instruksie bring. Allison (1993:186-187) toon aan dat Rabbiniese bronne getuienis lewer oor 'n verskeidenheid oortuigings omtrent die lot van die Tora in die Messiaanse era of die era wat sal kom. Daar is 'n hele spektrum wat strek vanaf diegene wat meen dat dit dieselfde sal bly tot diegene wat meen daar sal 'n nuwe Tora wees. ${ }^{6}$ Dit sou gerieflik wees om Matteus bloot in die lig van laasgenoemde te lees, maar die Rabbynse tekste hieroor dateer heelwat later as die eerste eeu. Tog is dit so dat die Rabbynse tekste die aandag daarop vestig dat sommige rabbi's baie spekulatief met die gedagte van die Tora in die Messiaanse tyd omgegaan het. Die volgende vraag ontstaan dan: Hoekom kon Matteus dit nie doen nie? Allison (1993) verwys na die feit dat Paulus na die 'wet van Christus' in Galasiërs 6:3 verwys. Die Hebreeuse ekwivalent waarin die woorde Tora van die Messias verskyn, kom voor in Mid Qoh.11:8. Dit lyk dus of pre-Christen Judaïsme reeds van 'n Messiaanse Tora gepraat het. Die argumentasie is hier te twyfelagtig om enige sekere gevolgtrekkings te maak. Tog is dit duidelik dat Paulus, wat hy ookal daarmee bedoel het, na Jesus as een wat sy eie vó $\mu$ o kan verwys het. Allison is oortuig dat Matteus ons ook met die vó $\mu$ o van die Messias in kontak bring - indien nie in terminologie nie, dan wel in inhoud.

Dit is veelseggend dat drie van die voorspellings van Jeremia 31:31-34 alles ' $n$ vervulling in Matteus vind: Jesus die Messias stel 'n nuwe verbond in (Jr 26:28), lê klem op die interne dimensies van die gebooie (5:21 e.v.) en Hy gee sy lewe as losprys vir baie $(20: 28 ; 26: 28)$. Verder is dit so dat baie kommentatore in Matteus 26:28 ('dit is die bloed van die nuwe verbond ... tot die vergifnis van sonde') 'n sinspeling op Jeremia 31:31 waarneem en op só 'n wyse die realisering van Jeremia se woorde in Jesus se dade verkondig (vgl. Luk 22:17; 1 Kor 11:25). Ons kan maar net beaam wat Allison (1993) sê:

I am lured to believe that Matthew 1-5 presents Jesus as the new lawgiver, the eschatological revealer and interpreter of Torah, the Messiah who brought the definitive, end-time revelation, a revelation for the heart, as foretold by Jeremiah's ancient oracle. (p. 190)

In hierdie studie het ons aangetoon hoe die geregtigheid van die Saligsprekings verband hou met hierdie eskatologiese 'definitive, end-time revelation'. Dit word gesien in die

6.Die Dooie Seerolle gee ondersteuning vir'n 'nuwe Tora'-gedagte (Ällison 1993:188) Sekere opmerkings in 1 QS IX. 9-II en CD VI.14 impliseer dat sekere wette, gebasee op hulle interpretasie van die Tora, in die toekoms'n verbetering sal ondergaan. Nog meer betekenisvol is die sogenaamde 'Tempel boekrolle'. Hierdie dokumente produseer nie net baie van die Pentateug-wetgewing nie, maar voeg ook by en verander sommige daarvan. Dit word in die eerste persoon enkelvoud met verwysing na God self gedoen. Allison (1993:188) wys daarop dat M.O. Wise argumenteer dat baie van die redaktor se uitlating van gedeeltes van argumenteer dat baie van die Deuteronomium 12-26 verduidelik kan word in terme van eskatologiese verwagting Die meeste van Deuteronomium se reëls aangaande vreemdelinge, slawe, uitleen en grensmerkers is uitgelaat, aangesien dit nie van toepassing is op die toekomstige era nie. Verder aanvaar die rol dat al 12 stamme in die land is soos die eskatologiese verwagting dit dikteer (ve. 10 Tempel. 57:11-12). Indien Wise korrek is, kan dit ' aanduiding wees dat pre-Christen Judaïsme nie net oor ' $n$ Messiaanse Tora gedink het nie, maar in werklikheid een geproduseer het. 
geregtigheid wat uit barmhartigheid, reinheid van hart en die maak van vrede bestaan.

\section{Die afloop van die Bergrede en geregtigheid}

Matteus het Jesus in die Bergrede (Matt 5:1-7:29) voorgestel as dié een wat die wil van God gesagvol verkondig het. Vanaf hoofstuk 8 word nou aangedui hoe Hy sy Goddelike gesag met die daad bevestig. Die klem op Jesus se lering word dus nou voortgesit met ' $n$ klem op sy dade. In drie episodes word daar in Matteus 8:1-17 vertel hoe Jesus na mense uitreik wat in die destydse Joodse samelewing nie gereken is nie: 'n melaatse, 'n nie-Joodse offisier en 'n vrou (Van Zyl 1999:1130; Nixon 1982:826). In al drie gevalle kan daar aangetoon word dat Jesus nou wys hoe lyk die geregtigheid van die Saligsprekings in die praktyk.

In Matteus 8:1 lees ons: 'En toe Hy van die berg afkom, het

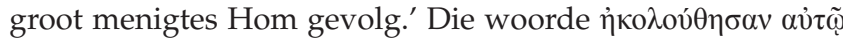
ő $\chi \lambda$ or $\pi$ o $\lambda \lambda$ oí (Nestle et al. 1993) is dieselfde as wat elders in Matteus met 'volg' vertaal word (vgl 8:19, 22-23). Só word daar 'n verband gelê tussen luister na Jesus se onderrig en praktiese navolging van Hom (Van Zyl 1999:1130).

Matteus 5:17-20 se eskatologiese verstaan en die verband met die geregtigheid van die Saligsprekings word finaal deur Matteus onderstreep as hy 'n definitiewe verband tussen die Bergrede en die reiniging van die melaatse lê. Viljoen (2014:1) wys daarop dat Jesus die ware bedoeling van die Wet hier beoefen wat ten doel het om die heilige gemeenskap van gelowiges in die Koninkryk van die hemel te vestig. Hierdie genesingsaksie is, volgens hom, nog 'n tree nader aan die koms van die Koninkryk van die hemel. Sodoende vind die reinheidswette hulle vervulling in Jesus. Viljoen meen kultiese reinheid verander na morele optrede vir die navolgers van Jesus as gevolg hiervan.

Die reiniging van die melaatse is nou 'n bewys van die eskatologiese Jesus en wat Hy vir sy volgelinge wil. Hy mag meer sê as Moses, omdat sy mag ook verder strek. In Matteus 8:2 vestig Matteus ons aandag op die feit dat dit juis 'n

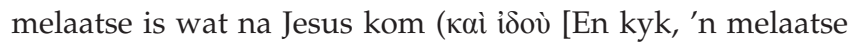
...]). Wanneer Jesus kom om die wet en die profete te vervul (Matt 5:17), is dit vir Hom moontlik om te doen wat geen priester uit die ou verbond kon doen nie: Hy reinig 'n melaatse. Die priesters kon wel vasstel of iemand weer rein was en hulle moes dit dan bekragtig met offers en 'n plegtige ritueel, maar meer as dit kon hulle nie doen nie. Inteendeel, die aanraak van 'n onreine sou ook die priester onrein maak. Die melaatse vertrou Jesus egter meer as Moses. Jesus raak die melaatse aan (Hy trek die onreinheid as 't ware na Homself toe) en sy wil is genoeg om die melaatse in 'n oogwink te genees (Matt 8:3). Dat die term reinheid hier gebruik word, is waarskynlik nie toevallig nie. Die feit dat Jesus die onreine aanraak en nie onrein word nie, maar die onreine laat rein word, bevestig dat Hy die een is wat 'n reinheid besit wat die priesters van die dag nie besit het nie.
Om daarop te wys dat hierdie gebeure 'n sigbare illustrasie van barmhartigheid is, sou oorbodig wees.

Dit is uiters belangrik om te besef dat dit alles egter nie in stryd was met Moses en die priesters in die tempel nie (Van Bruggen 1999:137). Die man kry die bevel om voorlopig met niemand te praat nie, maar om dadelik na die priesters te gaan om die offer wat deur Moses ingestel is (Lev 14), te bring (Matt 8:4). Dit is vir 'hulle 'n getuienis'. Die skare wat daar gestaan het, kon daardeur sien dat Jesus nie gekom het om die wet en die profete te ontbind nie, maar te vervul.

Deurdat die man die bevel kry om met niemand te praat nie, maar dadelik na die priester te gaan, word daar waarskynlik ook in die narratief aangedui dat Jesus die groot vredemaker is. Hy wil geen oproer of stryd veroorsaak met sy barmhartigheid nie.

In Matteus 8:5-13 reik Jesus uit na 'n hoofman oor honderd - dus 'n nie-Jood. Jesus se reaksie in Matteus 8:10-11 bevestig dit. Matteus 8:11-12 is waarskynlik weer 'n eskatologiese bevestiging van 'n gedeelte soos Jesaja 2:2-4 waar vermeld word hoe heidene na die Godstad sal stroom, terwyl die Jode - vir wie die koninkryk bedoel is - self onder God se oordeel sal kom. Hoe dit ook al sy, in hierdie perikoop is Jesus weereens besig met die bewys van barmhartigheid, en gegewe die historiese konflik tussen Jode en nie-Jode, is Hy hier ook besig om vredemaking te demonstreer.

In die verhaal van die vrou wat aan bloedvloeiing gely het (Matt 8:14-17), word Jesus se barmhartigheid en die feit dat Hy kan reinig juis omdat $H y$ ' $n$ reinheid besit wat die priesters van die dag nie gehad het nie, weereens bevestig.

\section{Slotsom en enkele implikasies}

In hierdie artikel is aangedui dat die betekenis van geregtigheid in die Bergrede in die struktuur van die Saligsprekings gevind word. Die geregtigheid van die Begrede het daarom alles te make met die bewys van barmhartigheid, reinheid van hart en die najaag van vrede. Daar is voorts aangetoon dat dit wat in die Saligsprekings gevind word juis die 'klein gebooie' is waarna Jesus in Matteus 5:17-20 verwys. Dit is hierdie gebooie wat nooit sal verdwyn nie en nie deur sy volgelinge gebreek mag word nie, aangesien dit die vervulling van die wet en die profete is. Jesus het juis gekom om die vervulling van die wet en die profete te weeg te bring. Anders gestel, dit is die geregtigheid wat by sy dissipels pas noudat Hy gekom het en die eschaton aangebreek het. Dit is niks anders nie as die geregtigheid wat meer is as die geregtigheid van die Fariseërs. Wanneer Matteus se fokus op Jesus as die een wat Israel se rol as God se seun oorneem, in gedagte gehou word, is dit baie duidelik dat Jesus nie net Israel se rol oorneem nie, maar dat Hy ook die finale Moses is wat op die berg 'n totaal nuwe riglyn aan sy volgelinge gee. Hy kom gee die finale Tora - dié Tora wat die ou Tora (Mosaïese wet) tot eskatologiese vervulling bring. Dit is hierdie Tora wat die riglyn vir die lewe van sy dissipels is en deur hulle geleef en verkondig moet word. Dit is die 
geregtigheid vir die bedeling waarna Jesaja reeds uitgesien het in Jesaja 60-61.

Hierdie bevindings het uiteraard implikasies vir die volgelinge van Jesus vandag. Die kerk moet ag gee op hierdie lering. Ons kan net kortliks na twee moontlike implikasies verwys:

1. Die gebruik van die lees van die Dekaloog aan die begin van elke erediens: Hierdie is ' $n$ instelling wat selde in sekere gereformeerde denominasies bevraagteken word. In die lig van hierdie artikel moet daar deeglik aandag aan hierdie aspek van die liturgie geskenk word. Die lees van die wet met sondebelydenis wat daarop volg, kan nie onnadenkend toegepas word nie. Die huidige gebruik in die meerderheid Gereformeerde denominasies kan onteenseglik 'n verkeerde interpretasie van Matteus 5:1720 tot gevolg hê. Die wet uit Eksodus 20 of Deuteronomeum 5 kan nie voorgelees word sonder om breedvoerig aan te dui dat Jesus die hele wet in vervulling kom bring het en ons daarom tot ' $n$ nuwe geregtigheid uitdaag nie. Indien dit nie gedoen word nie, kan dit daartoe lei dat Matteus 5:17-20 se uitsprake bloot gesien word as 'n bevestiging dat Jesus elke deel van die wet onveranderd kom bevestig. Hierdie artikel het aangedui dat dit nie mag gebeur nie. Dit is tog insiggewend dat die Dekaloog nie in die Vroeë Kerk en gedurende die vroeë Middeleeue in die erediens aangetref is nie (Barnard 1981:544).

2. Die riglyne vir die Christen se dankbaarheidslewe: Indien die bevindings van hierdie artikel rondom die geregtigheid wat Jesus nou by sy volgelinge soek, in teenstelling met die geregtigheid wat die Fariseërs nagejaag het, ernstig opgeneem word, kan die wet van Moses nie meer as altyd geldende, onveranderde riglyn vir geregtigheid en die Christen se dankbaarheidslewe gesien en hanteer word nie (Inst. 2.7.6). Die usus didacticus, of normatious [derde gebruik], of didaktiese gebruik van die sedewet as die reël vir dankbare gehoorsaamheid aan God wat redelik algemeen onder gereformeerdes aanvaar word (Berkhof 1988:613-615), moet in die lig van hierdie artikel se bevindings bevraagteken word. Die Bergede en die geregtigheid van die Saligspreking moet in die nadenke oor die Christen en die wet verreken word in die kerk se prediking en lering. Die riglyn vir die Christen se dankbaarheidslewe moet, in die lig van hierdie artikel, in die eskatologiese geregtigheid wat Jesus in die Bergrede leer, gevind word.

As slotsom kan daar dus gewaag word om te verklaar dat die Saligsprekings ' $n$ definisie van geregtigheid gee wat die sleutel tot 'n sinvolle eskatologiese interpretasie van Matteus 5:17-20 en Jesus se rol as eskatologiese Moses verskaf. Hierdie interpretasie help ons as Christene om beter te verstaan wat dit beteken om 'n geregtigheid te beoefen wat meer is as dié van die Fariseërs. Dit daag ons uit om barmhartigheid te beoefen oral waar ons onsself bevind, om te streef na reinhart van hart te midde van 'n samelewing wat dit bykans onmoontlik maak en dit daag ons uit om vrede tot stand te bring waar daar vyandskap heers.

\section{Erkenning Mededingende belange}

Die outeur verklaar dat hy geen finansiële of persoonlike verbintenis het met enige party wat hom nadelig kon beïnvloed het in die skryf van hierdie artikel nie.

\section{Outersbydrae}

J.D.D. was die enigste outeur betrokke by die skryf van die artikel.

\section{Etiese oorwegings}

Hierdie artikel volg alle etiese standaarde vir navorsing.

\section{Befondsing}

Hierdie navorsing het geen spesifieke toekenning ontvang van enige befondsingsagentskap in die openbare, kommersiële of nie-winsgewende sektore.

\section{Data beskikbaarheidsverklaring}

Data-deling is nie van toepassing op hierdie artikel nie, aangesien geen nuwe data in hierdie studie geskep of ontleed is nie.

\section{Vrywaring}

Die sienings en menings wat in hierdie artikel uitgedruk word, is dié van die outeur en weerspieël nie noodwendig die amptelike beleid of posisie van enige geaffilieerde agentskap van die outeurs nie.

\section{Literatuurverwysings}

Allison, D.C., 1993, The new Moses: A Matthean typology, Fortress, Minneapolis, MN. Barnard, A.C., 1985, Die erediens, NG Kerkboekhandel, Pretoria.

Berkhof, L., 1988, Systematic theology, Banner of Truth, Edinburgh.

Betz, H.D., 1995, The Sermon on the Mount including the Sermon on the plain (Matthew 5:3-7:27 and Luke 6:20-49), Fortress Press, Minneapolis, MN. (Hermeneia-A critical and historical commentary on the Bible).

Carson, D.A., 1984, Matthew. The Expositor's Bible Commetary, Baker, Grand Rapids, MI. Calvyn, J., 1984, Institusie van die Christelike godsdiens, Calvyn Jubileum Boekefonds, Potchefstroom.

Carter, W., 2000, 'Matthew and the margins: A socio-political and religious reading', Journal for the Study of the New Testament, suppl. ser. 204, pp. 1-140.

Combrink, H.J.B., 1991, 'Dissipelskap as die doen van God se wil in die wêreld,' in J.H. Roberts, W.S. Vorster, J.N. Vorster \& J. G. van der Watt (reds.), Teologie in konteks, pp.1-31, Orion, Pretoria.

Davies, W.D. \& Allison, D.C., 2004, Matthew 1-7, vol. 1, T\&T Clark, London. (International critical commentary).

Domeris, W.R., 1990, “'Blessed are you ..." (Matthew 5:1-12)', Journal of Theology for Southern Africa 73(1), 67-76.

Dumbrell, W.J. 1981, 'The logic of the role of the law in Matthew V 1-20', Novum Testamentum XXIII(I), 1-21. https://doi.org/10.1163/156853681X00016

Du Toit, P. la G., 2018, 'The fulfilment of the law according to Matthew 5:17: A dialectical approach', Acta Theologica 38(2), 49-69. https://doi.org/10.18820/ 23099089/actat.v38i2.4

France, R.T., 1985, The Gospel according to Matthew, Eerdmans, Grand Rapids, MI. (Tyndale New Testament commentaries).

France, R.T., 1989, Matthew: Evangelist and teacher, Paternoster, Exeter.

Holwerda, D.E., 1995, Jesus \& Isebel: One Covenant or two?, Eerdmans, Grand Rapids, MI.

Inst. sien Calvyn 1984. 
Keener, C.S., 2009, The Gospel of Matthew: A socio-rhetorical commentary, William B. Eerdmans, Grand Rapids, MI.

Koch, K., 1974, Was ist Formgeschichte? Neue Wege der Bibel exegese, Neukirchener Verlag, Neukirchener Verlag.

Lloyd-Jones, D.M., 1976, Studies in the Sermon on the Mount, William B. Eerdmans, Grand Rapids, MI.

Loader, W.R.G., 1997, Jesus' attitude towards the Law: A study of the Gospels, Moh Siebeck, Tübingen. (Wissenschaftliche Untersuchungenzum Neuen Testament 2. Reihe).

Louw, J.P. \& Nida, E.A., 1996, Greek-English lexicon of the New Testament: Based on semantic domains, in Scholar's Library: Gold, Logos Bible Software, 3 '06, CD-ROM, United Bible Societie, New York.

Moo, D., 1992, 'Law', in J.B. Green, I. McKnight \& H. Marshal (eds.), Dictionary of Jesus and the Gospels, pp. 817-882, IVP, Leicester.

Nestle, E., Nestle, E., Aland, B., Aland, K., Karavidopoulos, J., Martini, C.M. et al., 1993, The Greek New Testament, 27th edn., Deutsche Bibelgesellschaft, Stuttgart.

Nixon, R.E., 1982, 'Matthew', in J.A. Motyer \& A.M. Sibbs (eds.), New Bible Commentary, 3rd edn., pp. 813-850, IVP, Leicester.

Poythress, V., 1991, The shadow of Christ in the law of Moses, Presbyterian \& Reformed, Philipsburg, NJ.
Prinsloo, T.M., 1999, 'Jesaja', in W. Vosloo \& F. van Rensburg (reds.), Die Bybellennium: een volume kommentaar, pp.774-841, Christelike Uitgewers Maatskappy, Pretoria.

Stott, J.R.W., 1985, The message of the Sermon on the mount (Matthew 5-7): Christian counter-culture, InterVarsity Press, Downers Grove, IL.

Trout, B.M., 2015, 'The nature of the law's fulfilment in Matthew 5:17: An exegetical and theological study', In die Skriflig 49(1), Art. \#1910, 8 pages. http://dx.doi. org/10.4102/ids.v49i1.1910

Van Aarde, A., 1994, 'God-with-us, the dominant perspective in Matthew's story, and other essays', HTS Teologiese Studies/Theological Studies, suppl. 5, pp. 1-302.

Van Bruggen, J., 1999, Matteus: Het evangelie voor Israël, Kok, Kampen.

Van Zyl, H., 1999, 'Matteus', in W. Vosloo \& F. van Rensburg (reds.), Die Bybellennium: Een volume kommentaar, pp. 1111-1187, Christelike Uitgewers Maatskappy, Pretoria.

Viljoen, F.P., 2007, 'Fulfilment in Matthew', Verbum et Ecclesia 28(1), 301-324. https:// doi.org/10.4102/ve.v28i1.109

Viljoen, F.P., 2013, 'Righteousness and identity formation in the Sermon on the Mount', HTS Teologiese Studies/Theological Studies 69(1), 1-10. Art. \#1300, 10 pages. http://dx.doi.org/10.4102/hts.v69i1.1300

Viljoen, F.P., 2014, 'Jesus healing a leper and the purity law in Matthew', In die Skriflig 48(2), 1-7. Art. \#1751, 7 pages. http://dx.doi.org/10.4102/ids.v48i2.1751

Wright, N.T., 1996, Jesus and the victory of God, Fortress, Minneapolis, MN. 